\title{
Formation of students' competitiveness in the vuca world
}

\section{Formación de la competitividad de los estudiantes en el mundo vuca}

\author{
Mikhail A. Rodionov \\ https://orcid.org/0000-0003-2213-9997 \\ Penza State University, Penza, Russia. \\ Julia M. Tsarapkina \\ julia_carapkina@mail.ru \\ https://orcid.org/0000-0002-3807-4211 \\ Russian State Agrarian University - Moscow Timiryazev Agricultural Academy, Moscow, \\ Russia. \\ Julia A. Kulagina \\ kulagina_yu.a@mail.ru \\ https://orcid.org/0000-0002-8892-0367 \\ Penza State Technological University, Penza, Russia. \\ Irina M. Morozova \\ 89063981816@mail.ru \\ https://orcid.org/0000-0003-2249-8332 \\ Penza State Technological University, Penza, Russia. \\ Nina A. Tkacheva \\ https://orcid.org/0000-0002-7545-6358 \\ Federal State Budget Educational Institution of Higher Education «Industrial University \\ of Tyumen», Tyumen, Russia.
}

\section{Abstract}

Recibido: 6/08/21

Aceptado: 5/11/21

The purpose of the article is to study the influence of the Vuca-world on the professional training of students and their competitiveness. The study presents an analysis of adaptations of an agile approach that meets the requirements of Vuca, a test of the formation of the level of competitiveness of students of a higher education institution according to the selected criteria. The study found that the training of students in the Vuca-world is becoming more technological, aimed at the formation of independent and creative specialists who can solve problems in interaction. The level of students' competitiveness in the new environment is getting higher.

Key Words: Vuca world, agile approach, professional training, uncertainty, electronic technologies. 


\section{Resumen}

El propósito del artículo es estudiar la influencia del mundo Vuca en la formación profesional de los estudiantes y su competitividad. El estudio presenta un análisis de adaptaciones de un enfoque ágil que cumple con los requisitos de Vuca, una prueba de la formación del nivel de competitividad de los estudiantes de una institución de educación superior según los criterios seleccionados. El estudio encontró que la formación de los estudiantes en el mundo Vuca se está volviendo más tecnológica, dirigida a la formación de especialistas independientes y creativos que puedan resolver problemas en la interacción. El nivel de competitividad de los estudiantes en el nuevo entorno es cada vez mayor.

Palabras clave: mundo Vuca, enfoque ágil, formación profesional, incertidumbre, tecnologías electrónicas.

\section{Introduction}

Describing the modern world, experts use the term Vuca, which implies life activity in conditions of variability and complete uncertainty. Vuca-world makes lifelong learning and continuous professional self-improvement a global trend.

The relevance of training a modern specialist who can quickly adapt to constantly changing conditions is increasing (Yarygin et al., 2019b).

The formation of a learner's competence should be built by the basic concepts that characterize the Vuca world: instability, uncertainty, complexity and ambiguity (Dobudko et al., 2019). The student's ability to quickly and creatively solve professional problems in these conditions determines his demand in the labor market.

In the context of the third industrial revolution, the traditional approach to vocational training of students is losing its relevance. The Vuca world emerged in opposition to the SPOD world (stable, predictable, simple and definite) (Yarygin et al., 2019a). A sharp leap in the development of electronic technologies and the expansion of the information field forces modern vocational education to introduce appropriate changes to improve the quality of education, bringing it by the requirements of the state to a competent specialist who can compete in the global labor market (Vaganova et al., 2019).

The organization of the educational process is acquiring new features. The role of students' independence, forecasting skill, risk vision and the ability to use technical means in their work, to act in conditions of uncertainty is growing.

In shaping student competitiveness, higher education institutions should rely on megatrends that shape the future of education (Pinkovetskaia et al., 2020). It is worth mentioning digitalization and automation (the modern era can be considered a new 
industrial revolution), demographic changes (declining birth rates, diversity of cultural needs, and others).

In the Vuca world, the agile approach, which was originally used in the business industry and has shown its effectiveness in startups and small companies, is becoming increasingly important in training a competitive specialist. The transfer of the approach to the sphere of vocational education will ensure the training of a specialist who can navigate in modern professional conditions (Ponachugin \& Lapygin, 2019).

The approach describes a system of principles and values that allow for flexible teamwork (Shashlo et al., 2018). The agile approach allows you to visualize progress for all project participants and record changes that are taking place, plan work on a common task with time intervals with a fixed duration.

This approach also reflects the modern vision of scholars of education development specialists. For the formation of competent, in-demand specialists, it is already necessary to take into account the components on which the formed educational communities are based.

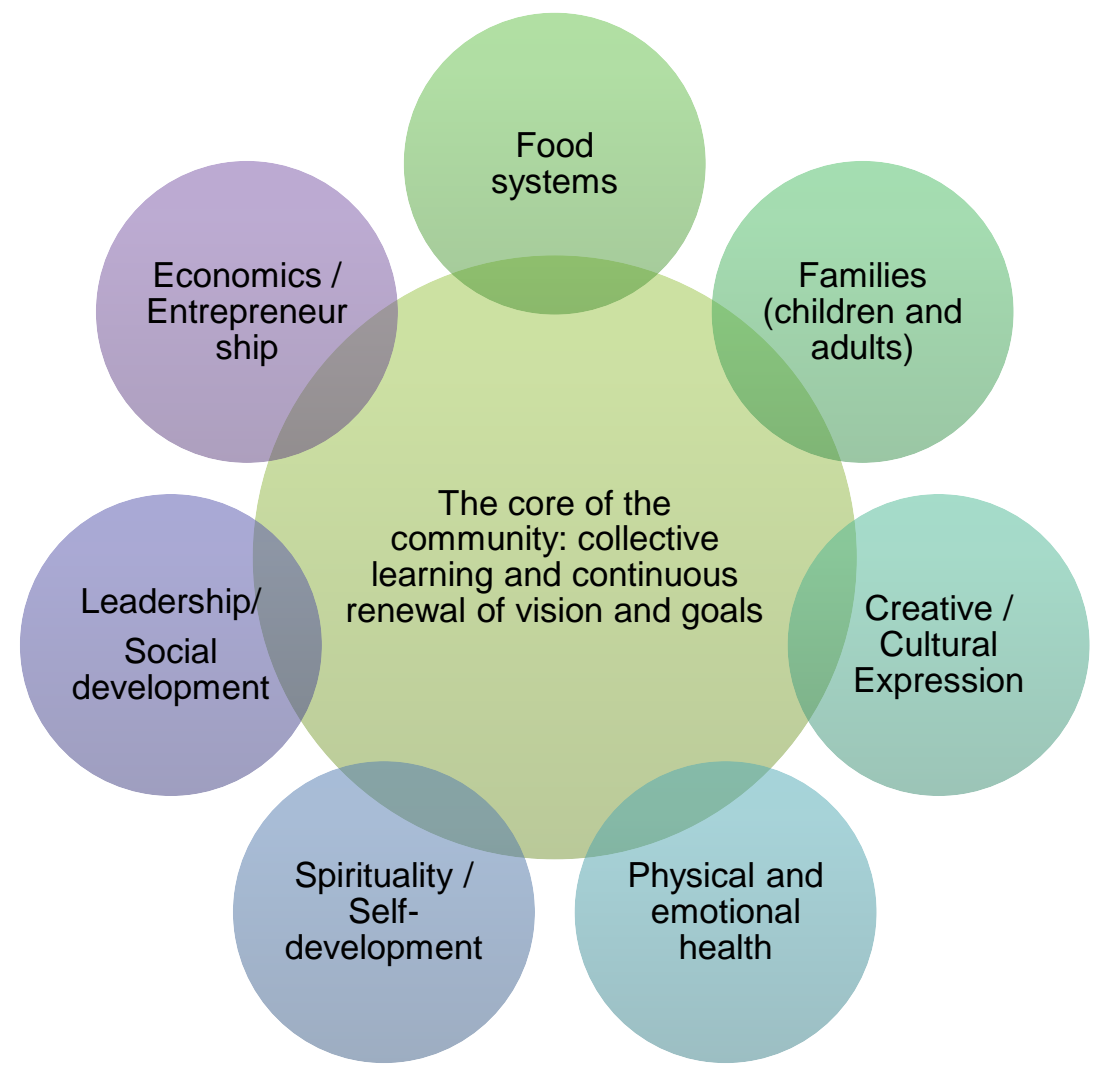

Fig. 1. Components of Emerging Learning Communities (Global Partnership for Education Leaders in Moscow) (Luksha, 2018) 
Developing educational communities make it possible to implement the format of collective education of different ages and joint creativity, which supports the exchange of knowledge in different areas of human life throughout life.

With the emerging changes in society, there is a need to study the influence of the Vucaworld on the professional training of students, the formation of their competitiveness.

\section{Theoretical framework}

The Vuca-world is characterized by signs that reflect the activities of the society in innovative conditions: high speed of new information emergence and obsolescence of existing information (also, these are large amounts of data), content can become outdated in 2-3 years and faster; active development of information technologies and communication systems, development of end-to-end technologies; the emergence of new demanded and highly paid professions, the withering away of old ones or their transition to an automated mode (Kiseleva et al., 2019).

A competitive specialist in the modern world has the following skills: mental flexibility (the ability to respond appropriately to a situation that has arisen and take adequate measures) (Shcerbakova \& Shcerbakova, 2019); the ability to quickly analyze situations and tasks; creative thinking; interpersonal sensitivity (the ability to find a common language with different people); susceptibility to new things (Misakov et al., 2019). A competitive specialist in the Vuca world can select several options for solving problems and not panic in difficult situations, soberly react to the circumstances that have arisen.

Many scientists, revealing the peculiarities of life and learning in the Vuca world, highlight the agile approach, which allows you to build effective work face to face.

This approach came from the IT industry and has spread to many areas, including education (Pichugina \& Bondarchuk, 2019). Building project activities of students based on this approach allows you to distribute the responsibilities of the participants evenly.

Agile means easy and quick change. A large project can be divided into several small ones and thus the highest priority ones can be highlighted. So the team will know for sure which of the tasks is most important for the progress of the entire project. Since this approach came from the IT sphere, the project divided into parts (small subtasks) are called user stories, and the time interval for which the subtask is completed is called a sprint.

The table presents the values of the agile approach in software development and the adapted values for professional education (Manokin et al., 2018). 
Table 1.

Adapted values of the agile- approach (M.A. Manokin)

\begin{tabular}{ll}
\hline Agile values in software development & Adapted values in education \\
\hline $\begin{array}{l}\text { The value of people and their interactions } \\
\text { is higher than the value of processes and } \\
\text { tools }\end{array}$ & $\begin{array}{l}\text { The value of the subjects of the } \\
\text { educational process and their interaction } \\
\text { is higher than the administration and } \\
\text { infrastructure }\end{array}$ \\
$\begin{array}{l}\text { Work product value is higher than complex } \\
\text { documentation }\end{array}$ & $\begin{array}{l}\text { The value of employment and } \\
\text { competitiveness is higher than a rigid } \\
\text { program and grades }\end{array}$ \\
\hline $\begin{array}{l}\text { Customer interaction value is higher than } \\
\text { the contractual relationship }\end{array}$ & $\begin{array}{l}\text { The value of competencies and interaction } \\
\text { is higher than complaints and competition }\end{array}$ \\
\hline $\begin{array}{l}\text { The value of reacting to change is greater } \\
\text { than following a precise plan. }\end{array}$ & $\begin{array}{l}\text { The value of thinking, the ability for } \\
\text { continuous self-improvement, reaction to } \\
\text { changes, increasing the flexibility of the }\end{array}$ \\
& $\begin{array}{l}\text { learning process is higher than the ability } \\
\text { to perform routine work and follow a plan }\end{array}$ \\
\hline
\end{tabular}

Agile values in education are primarily aimed at organizing collaboration and creative joint achievement of goals (Shcerbakova et al., 2019). The table shows that the significance of the still prevailing convergent conditions, in which processes are more important than human ideas, is decreasing. Processes must be automated, while the human task is to discover new ideas and expand opportunities. The approach puts the competitiveness and employment of the graduate higher than his marks throughout the training.

Vocational education should be based on data on the emergence of new demanded spheres of activity, including the creative economy, cyber economy, the environmental sphere, human-centered services, and a new technological sector (Kidina, 2020). Orientation towards new professions is one of the main features of the Vuca world (Kharytonov et al., 2019).

As L.V. Shper, in the new educational process, it is important to observe the following principles: implementation of work in a system of interrelated processes; the presence of variations; awareness of variations and their reduction - allows you to make processes more operational and efficient (Shper, 2019).

\section{Methodology}

The study is aimed at checking the formation of the level of competitiveness of students of a higher educational institution. The training of the students took place taking into account the agile approach. The test of competitiveness was carried out according to several criteria that reflect the student's ability to carry out professional activities in the 
Vuca-world (the ability to make responsible decisions, the ability to quickly master new material, high efficiency, creativity, sociability, the desire for constant self-improvement, focus on achieving high-quality results).

The table shows the criteria for the competitiveness of an individual.

Table 2.

Student competitiveness criteria.

\begin{tabular}{|c|c|c|}
\hline \multicolumn{3}{|r|}{ Competitiveness } \\
\hline No. & Component & Characteristic \\
\hline 1 & $\begin{array}{l}\text { Ability to make } \\
\text { responsible } \\
\text { decisions }\end{array}$ & $\begin{array}{l}\text { The student is responsible for completing assignments, is } \\
\text { responsible for his role and functions in the project, works } \\
\text { for a team result }\end{array}$ \\
\hline 2 & $\begin{array}{l}\text { Ability to quickly } \\
\text { master new material }\end{array}$ & $\begin{array}{l}\text { w material and applies } \\
\text { key idea and relevant } \\
\text { g }\end{array}$ \\
\hline 3 & High efficiency & $\begin{array}{l}\text { on time, showing the } \\
\text { nts for a specific type of }\end{array}$ \\
\hline 4 & Creativity & orts to non- \\
\hline 5 & Sociability & $\begin{array}{l}\text { The student easily interacts with other participants in the } \\
\text { educational process, overcomes conflicts to achieve } \\
\text { common goals }\end{array}$ \\
\hline 6 & $\begin{array}{l}\text { Striving for constant } \\
\text { self-improvement }\end{array}$ & $\begin{array}{l}\text { The student realizes the importance of professional } \\
\text { development for the implementation of professional } \\
\text { activities at a high level, also, he realizes the essence of } \\
\text { the concept of lifelong learning }\end{array}$ \\
\hline 7 & $\begin{array}{lr}\text { Commitment } & \text { to } \\
\text { achieving quality } \\
\text { results }\end{array}$ & $\begin{array}{l}\text { The student strives to achieve high-quality results and } \\
\text { chooses the appropriate ways to achieve them, build their } \\
\text { activities and the activities of the team, each of the } \\
\text { students controls the process }\end{array}$ \\
\hline 8 & $\begin{array}{l}\text { Use of electronic } \\
\text { technologies in their } \\
\text { activities }\end{array}$ & $\begin{array}{l}\text { The student uses in the learning process technical } \\
\text { capabilities that promote active interaction, the most rapid } \\
\text { achievement of the set goals }\end{array}$ \\
\hline
\end{tabular}

The results were categorized by level: high, medium, low.

\section{Results and discussion}

The preparation of a student in the Vuca-world is based on the idea of completing assignments independently with the consulting role of a teacher. 
In the classroom, the teacher initiates a discussion of issues, meets with them at consultations and communicates remotely using electronic technologies.

Students carry out projects in groups. The process, as mentioned above, is based on an agile approach. Students in the process of completing the assignment change roles. Part of the team completes the task, another part of it observes and suggests ways to solve the problem, corrects errors, and controls the process. Then they change places. The basis of the students' work is collaboration - joint independent fulfillment of tasks. At the same time, the work of students is constantly monitored. The student's knowledge is assessed through direct feedback, monitoring and feedback. Direct feedback allows you to identify the initial knowledge of students. Current control allows you to timely adjust the learning process. Feedback makes it possible to analyze the results.

Competitiveness is determined by the student's ability to make prompt and creative decisions to achieve professional goals. Therefore, according to Vuca, in the process of preparation at the university, students develop the ability to see (vision of the long-term direction of movement and development of the project, the ability to see the result at the beginning of work); understanding (in various companies there is risk management, which allows you to systematize data and analyze factors that may have an impact on the business, already at the preparation stage, tools are used to form students' understanding of how to achieve their goals in a short time in existing conditions); clarity (the formation of systematic thinking to overcome complexity, the development of critical and creative thinking. In a difficult situation, the student identifies the essence of risk and simplifies it); speed (allows you to overcome the ambiguity of tasks and quickly respond to the task by choosing an alternative scenario).

One of the most relevant options for organizing student activities in modern conditions is an electronic educational platform. Currently, she is used both in face-to-face classes and in remote conditions.

The technical capabilities and agile approach used to allow students to independently complete assignments, develop appropriate solutions in the interests of the working group.

Table 3 shows the characteristics of each level of training. 
Table 3.

Student competitiveness levels.

\begin{tabular}{|c|c|}
\hline \multicolumn{2}{|r|}{ Competitiveness } \\
\hline Level & Characteristic \\
\hline High & $\begin{array}{l}\text { The student is responsible for completing assignments, responsible for their } \\
\text { role and their functions in the project. } \\
\text { The student quickly memorizes new material and applies it in } \\
\text { practice, structures information. The student completes the work on time, } \\
\text { showing the success of meeting the requirements for a specific type of } \\
\text { activity. The student effectively uses technical capabilities in } \\
\text { the learning process. The student strives to achieve quality results. The } \\
\text { student realizes the importance of professional development for the } \\
\text { implementation of professional activities at a high level. The student completes } \\
\text { the work on time. The student easily interacts with other participants in the } \\
\text { educational process. The student solves questions in a variety of ways. }\end{array}$ \\
\hline Middle & $\begin{array}{l}\text { The student approaches the assignments responsibly. The student tries to } \\
\text { memorize new material and applies it in practice. The student completes } \\
\text { the work on time. The student uses technical capabilities in } \\
\text { the learning process. The student strives to achieve quality results. The } \\
\text { student realizes the importance of professional development. The student } \\
\text { completes the work on time. The student tries to effectively interact with other } \\
\text { project participants and find solutions in difficult situations. }\end{array}$ \\
\hline Low & $\begin{array}{l}\text { The student does not seek to participate in projects and takes responsibility for } \\
\text { his role in them. } \\
\text { The student memorizes new material, but does not apply it in practice. The } \\
\text { student does not complete the work on time. The student uses technical } \\
\text { capabilities in the learning process. The student is not focused on achieving } \\
\text { quality results. The student does not understand the importance of } \\
\text { professional development. The student does not fit into the deadline for } \\
\text { completing the work. The student interacts with other participants in the } \\
\text { educational process. The student does not show interest in solving problems } \\
\text { in different ways. }\end{array}$ \\
\hline
\end{tabular}

During the learning process, students took part in projects of various levels. The figure shows the results of the formation of the competitiveness of students of a higher educational institution in the framework of the Vuca-environment. 


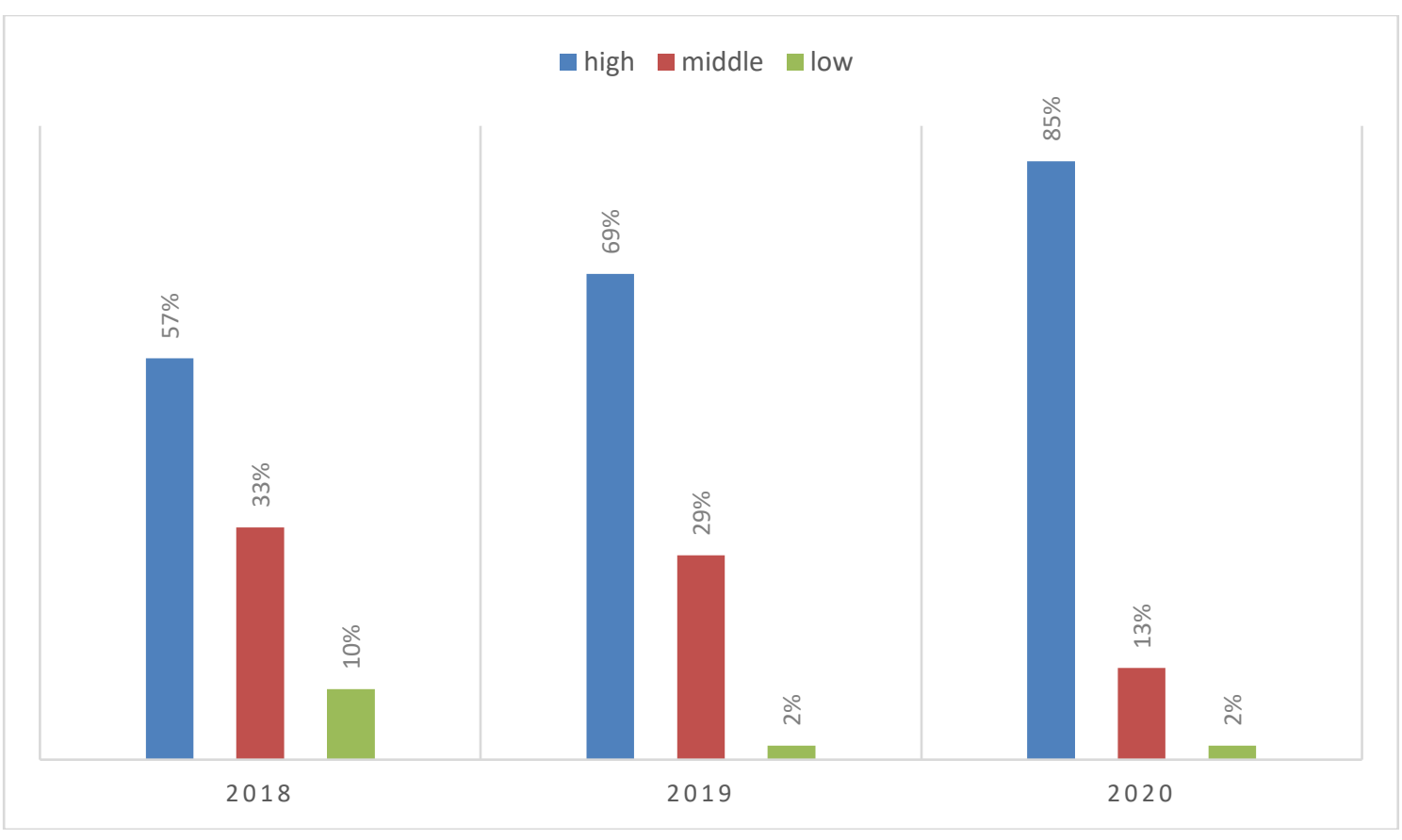

Fig. 2. The level of formation of the competitiveness of students of a higher educational institution

There is a high level of responsibility. Students get creative with projects and complete them in a limited time. Show the ability to independently and promptly solve emerging problems.

The number of students capable of adapting to the modern professional Vuca world is growing every year.

\section{Conclusions}

Vuca-world has a significant impact on the training of a modern specialist, the restructuring of teaching methods. The formation of competitiveness is based on ideas related to the ability to navigate in rapidly changing conditions and take on various roles, both as a performer and as a leader, therefore, in the formation of a competent specialist, modern techniques are used that allow students to independently and creatively complete tasks. Higher education institutions are introducing more and more electronic tools in the educational process, which allow students to interact more actively, while receiving timely advice from the teacher.

The conducted research shows an increase in the competitiveness of students over the past three years. Formation of competitiveness in the new environment with the inclusion of an agile approach is achieved at the fastest pace. 
Mikhail A. Rodionov, Julia M. Tsarapkina, Julia A. Kulagina, Irina M. Morozova, Nina A. Tkacheva.

The development of the Vuca-world necessitates further monitoring of the educational process and its improvement by modern requirements.

\section{Bibliographic references}

Dobudko, T.V., Korostelev, A.A., Gorbatov, S.V., Kurochkin, A.V., \& Akhmetov, L.G. (2019). The organization of the university educational process in terms of digitalization of education. Humanities and Social Sciences Reviews. 7(4), pp. 1148-1154.

Kidina, I. M. (2020). Management of the pedagogical collective in the conditions of implementing distance learning. Baltic Humanitarian Journal. (Baltic Humanitarian Journal), Vol. 9 No 4 (33), pp. 93-96.

Kharytonov, E., Kharytonova, O., Tolmachevska, Y., Fasii, B., \& Tkalych, M. (2019). Information Security and Means of Its Legal Support. Amazonia Investiga, 8(19), 255-265. https://amazoniainvestiga.info/index.php/amazonia/article/view/227

Kiseleva, O., Lebedev, A., Pinkovetskaia, I., Rojas-Bahamón, M., \& Arbeláez Campillo, D. (2019). Specialization and concentration of small and medium enterprises employees: Russian data. Amazonia Investiga, 8(20), 6-15. Retrieved from https://amazoniainvestiga.info/index.php/amazonia/article/view/59

Luksha, P. (2018). "Education for a Complex World: Why, What and How": Report on the Forum (Skolkovo, October 9, 2018), Global Partnership for Education Leaders in Moscow. Luksha. 212.

Manokin, M. A., Ozhegova, A. R., \& Shenkman, E. A. (2018). Agile methodology in educational environment. University Management: Practice and Analysis, $22 \quad$ (4 (116)), 83-96.

Misakov, V., Tsurova, L., Yandarbayeva, L., Tkhamadokova, I., \& Gapurovna, G. (2019). Certification of A Regional Economic Complex as a Highly Effective Tool for analysis and diagnostics of its development. Amazonia Investiga, 8(20), 451-458. Retrieved https://amazoniainvestiga.info/index.php/amazonia/article/view/174

Pichugina, G.A., \& Bondarchuk, A.I. (2019). Structure of the training case in the organization of the educational process. Humanitarian balkan research, 2(4), pp. 5-7.

Pinkovetskaia, I., Berezina, N., \& Sverdlikova, E. (2020). The main reasons for the exit of entrepreneurs from business. Amazonia Investiga, 9(26), 68-73. https://doi.org/10.34069/Al/2020.26.02.7

Pinkovetskaia, I., Kryukova, L., Arbeláez, D., \& Rojas-Bahamon, M. (2019). Female Entrepreneurship: Types of Economic. Activity. Tarih kultur ve sanat arastirmalari dergisi-journal of history culture and art research, 8(2), 253-265. DOI: 10.7596/taksad.v8i2.2153

Ponachugin, A.V., \& Lapygin, Yu.N. (2019). Digital Educational Resources of the University: Design, Analysis and Expertise. (Vestnik of Minin University), Vol. 7 (2), 5 (in Russ)

Shashlo, N., Petruk, G., \& Korostelev, A. (2018). Determinants of integration interaction among the subjects of the entrepreneurial innovation ecosystem of macro region. 


\section{Geduweb}

Revista de Tecnología de Información y Comunicación en Educación • Volumen 15, № 3. Septiembre-diciembre 2021

Amazonia Investiga, 7(13), 351-363. Retrieved from https://amazoniainvestiga.info/index.php/amazonia/article/view/569

Shper, V. L. (2019). The system of in-depth knowledge and problems of education in the XXI century. Science Research, 179-199.

Shcerbakova, E.V., \& Shcerbakova, T. N. (2019). Experience of Use of Remote Computer Technologies at The Organization of Independent Work of Students in the Conditions of a Mark and rating system. Baltic Humanitarian Journal. (Baltic Humanitarian Journal), Vol. 8, No 4 (29), pp. 192-195.

Vaganova, O.I., Korostelev, A.A., Smirnova, Z.V., Abramova, N.S., Dolmatov, S.N. (2019). Improving teachers' professionalism through the development of creativity. International Journal of Innovative Technology and Exploring Engineering, 8(8), pp. 630-634

Yarygin, O.N., Korostelev, A.A., Akhmetov, L.G., \& Maseleno, A. (2019a). Modeling of competence as a tool of goal setting for education in modern society. International Journal of Recent Technology and Engineering, 7(6), pp. 72-77.

Yarygin, O.N., Korostelev, A.A, Mukhutdinov, R.H., \& Maseleno, A. (2019b). Elections and russian citizens residing overseas: Prospects for internet voting. International Journal of Recent Technology and Engineering, 7(6), pp. 52-57 